\title{
12. Fokozatosság elve és átfogó védelem: a különleges jogrend Észtországban
}

\author{
DORNFELD LÁSZLÓ
}

\section{A különleges jogrend allkotmányos és törvényi szintű szabályozása és esetkörei}

\begin{abstract}
A különleges jogrend vonatkozásában Észtországban mind az 1992-es alkotmány, ${ }^{1}$ mind bizonyos törvények tartalmaznak rendelkezéseket. Az alkotmány X. fejezete, amely a honvédelem témakörével foglalkozik, meghatározza a különleges jogrendi esetköröket: a szükségállapotot (erakorraline seisukord), ${ }^{2}$ valamint a hadiállapotot (sõjaseisukord). ${ }^{3} \mathrm{Az}$ alkotmányos szabályozás azonban csak a legszúkebb keretekre terjed ki, így csak azt mondja ki, hogy ki jogosult a különleges jogrend elrendelésére, milyen esetben és milyen időtartamra. A további szabályozás mindkét esetben külön törvényben található. Előbbi esetén a honvédelmi törvény tartalmaz rendelkezéseket, ${ }^{4}$ míg utóbbi kapcsán a szükségállapoti törvényben találhatók részletszabályok. ${ }^{5}$
\end{abstract}

I Az Észt Köztársaság alkotmánya (Eesti Vabariigi põhiseadus 1992. 06. 28.) (a továbbiakban: alkotmány).

2 Alkotmány 129. szakasz (a hivatalos angol nyelvú fordítás a state of emergency kifejezést használja).

3 Alkotmány 128. szakasz (a hivatalos angol nyelvủ fordítás a state of war kifejezést használja).

4 Honvédelmi törvény (Riigikaitseseadus 2015. 02. 11.) (a továbbiakban: Honvédelmi tv.).

5 Szükségállapoti törvény (Erakorralise seisukorra seadus 1996. 01. 10.) (a továbbiakban: Szükségállapoti tv.).

Dr. Dornfeld László

laszlo.dornfeld@mfi.gov.hu

kutató (Mádl Ferenc Összehasonlító Jogi Intézet)

Dornfeld, L. (2021) 'Fokozatosság elve és átfogó védelem: a különleges jogrend Észtországban' in Nagy, Z., Horváth, A. (szerk.) A különleges jogrend és nemzeti szabályozási modelljei, 277-300. o. Budapest: Mádl Ferenc Összehasonlító Jogi Intézet.

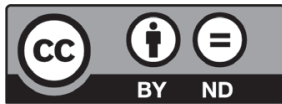


A harmadik legfontosabb törvény a kérdéskörben a veszélyhelyzeti törvény, ${ }^{6}$ amelyben a szükségállapotot el nem érő két szint kerül szabályozásra. ${ }^{7}$ Ezek a válsághelyzet (hädaolukord), ${ }^{8}$ valamint a veszélyhelyzet (eriolukord). ${ }^{9} \mathrm{Az}$ említett kifejezések nem szerepelnek az alkotmányban, így bár különleges felhatalmazást adnak, nem tekinthetók különleges jogrendi esetkörnek. Ennek megfelelően ezek a kategóriák egy későbbi pontban kerülnek részletes tárgyalásra. A két esetkör közötti különbséget az alkotmány is egyértelmúvé teszi: míg a Honvédelmi tv. és a Szükségállapoti tv. csak kétharmaddal módosítható, addig a Veszélyhelyzeti tv. nem szerepel a felsorolásban. ${ }^{10}$

A Honvédelmi tv. is megkülönböztet további esetköröket a hadiállapot előtt a helyzet súlyosságától függően; ezek az általános (üldine kaitsevalmidus) és a fokozott védelmi készültség (kôrgendatud kaitsevalmidus). ${ }^{11}$ Ezek szintén nem tekinthetők különleges jogrendnek, hanem az arra való felkészülést segítik elő, így később kerülnek tárgyalásra.

A fentiek értelmében Észtországban két különleges jogrendi esetkör különíthető el egymástól, a szükségállapot és a hadiállapot. A kettő között egyértelmú fokozatosság állapítható meg, ugyanis a szükségállapot véget ér a hadiállapot bevezetésével. ${ }^{12} \mathrm{~A}$ hadiállapot súlyosságát jelzi az is, hogy míg a szükségállapot elrendelésére csak határozott időre kerülhet sor, addig a hadiállapotot határozatlan időre rendelik el, és külön kell dönteni megszüntetéséről.

A szükségállapotot az alkotmány alapján az észt alkotmányos rendet érő fenyegetés esetén rendelheti el a parlament, a köztársasági elnök, a kormány vagy a törvényhozás képviselői többségének a javaslatára az ország egész területén legfeljebb három hónapos időtartamra. ${ }^{13}$ A szükségállapoti törvény pontosítja, mi az a három feltétel, ami szükséges az elrendeléshez: egyrészt Észtország alkotmányos rendjét fenyegetés éri, másrészt ez csak a különleges jogrend eszközeivel hárítható el, harmadrészt pedig a köztársasági elnök javaslatára a törvényhozás többsége támogatja azt. A törvény részletesebben meghatározza, mi tekinthető olyan fenyegetésnek, amely alapján a különleges jogrend elrendelhetô: $:^{14}$

— az alkotmányos rend megdöntésére irányuló erőszakos kísérlet;

- terrorista tevékenység;

6 Veszélyhelyzeti törvény (Hädaolukorra seadus 2017. 02. 08.) (a továbbiakban: Veszélyhelyzeti tv.).

7 Összességében tehát három szintje van a veszélyhelyzetnek, ezek súlyosság szempontjából: vészhelyzet, válsághelyzet, szükségállapot (Maruste, 2020).

8 A Veszélyhelyzeti tv. a hädaolukord kifejezést használja, amely a törvény hivatalos angol nyelvú változatában az emergency fordítást kapta.

9 A Veszélyhelyzeti tv. az eriolukord kifejezést használja, amely a törvény hivatalos angol nyelvú változatában az emergency situation fordítást kapta.

10 Alkotmány 104. szakasz (Maruste, 2020).

11 Honvédelmi tv. 12. szakasz (hivatalos angol fordításban: general defence readiness, illetve increased defence readiness).

12 Szükségállapoti tv. 16. szakasz.

13 Alkotmány 129. szakasz.

14 Szükségállapoti tv. 2-3. szakasz. 
- erőszakos kollektív kényszerítés;

— kiterjedt belső konfliktus különböző csoportok között;

— Észtország területe egy részének erőszakos elszigetelése;

- tartós erőszakos belső konfliktus.

Az alkotmányt érintő fenyegetésekről az állami szervek, községi és városi önkormányzatok haladéktalanul értesíteni kötelesek a köztársasági elnököt, a kormányt, illetve a védelmi erôk parancsnokát. ${ }^{15}$

A szükségállapot bevezetését illetően a törvény részletes szabályozást tartalmaz. ${ }^{16}$ Ebben szerep jut a kormány Válságbizottságának (Vabariigi Valitsuse kriisikomisjoni), valamint a Honvédelmi Tanácsnak (Riigikaitse Nốukogu). Mindkét szerv tanácsadó, elemző jellegú feladatot lát el, előbbi a kormány, ${ }^{17}$ utóbbi a köztársasági elnök mellett. ${ }^{18} \mathrm{~A}$ két szerv mellett a kormány is összeül, hogy tárgyaljon a szükségállapot bevezetésének indokoltságáról, majd a köztársasági elnök, mielőtt a javaslatot a törvényhozás elé vinné, azon személyekhez vagy csoportokhoz fordul, akiknek tevékenysége veszélyt jelent az észt alkotmányos rendre, és felszólítja őket ennek befejezésére. Ez a megkeresés tömegkommunikációs eszközök útján történik, a mûsorszolgáltatók kötelesek a felhívást változatlanul és azonnal közreadni. Amennyiben a felhívásnak nem tesznek azonnal eleget, az elnök a parlament elé viszi a javaslatot. ${ }^{19}$

Ez az utóbbi követelmény ugyanakkor a kormány által beterjesztett szükségállapoti javaslatra nem vonatkozik. A javaslatnak - terjessze bár be a köztársasági elnök vagy a kormány - tartalmaznia kell az elrendelésére okot adó alkotmányos fenyegetést is. Amennyiben a javaslat benyújtásakor a parlament nem ülésezik, a köztársasági elnök vagy a kormány írott javaslatot nyújt be a parlament elnökének rendkívüli ülés összehívására, a javaslat benyújtásától számított legalább 8 órán belül. Amennyiben a szükségállapoti javaslatot rendes ülésszakban terjesztik be, írott javaslatot kell benyújtani a parlament elnökének, hogy azonnal hívjon össze egy ülést. ${ }^{20} \mathrm{~A}$ parlament határozatában rendelkezni kell a szükségállapot alkotmány szerinti elrendeléséről, meg kell jelölni a bevezetés okát, valamint annak időtartamát. A határozat a nemzeti tömegtájékoztatásban való közzététele után válik hatályossá, ezt a músorszolgáltatóknak változatlanul és azonnal közzé kell tenniük. A határozat elfogadását követő első munkanapon azt közzé kell tenni az ország hivatalos lapjában is. ${ }^{21}$

15 Szükségállapoti tv. 7. szakasz.

16 Szükségállapoti tv. 8-11. szakasz.

17 A kormány válságbizottságának jogállásáról szóló kormányrendelet (Vabariigi Valitsuse kriisikomisjoni põhimäärus 2017. 06. 27.).

18 Lásd a köztársasági elnök honlapját: www.president.ee/en/president/institutions/1031-national-defencecouncil/5261-rules-of-procedure-of-the-national-defence-council-/layout-institution.html (Letöltve: 2020. december 5.).

19 Szükségállapoti tv. 12. szakasz.

20 Szükségállapoti tv. 13. szakasz.

21 Szükségállapoti tv. 14. szakasz. 
A szükségállapot bevezetése a krízishelyzet megoldásához három fontos szereplőnek juttat jogosítványokat: a kormánynak, a miniszterelnöknek mint a rendkívüli helyzet kezeléséért felelős vezetônek és a belügyminiszternek mint a belbiztonságért felelős vezetônek. Közöttük egyértelmú hierarchia figyelhető meg, ugyanis a kormány mind a két másik szereplö, míg a miniszterelnök a belügyminiszter utasításait visszavonhatja. ${ }^{22}$ Míg a kormány elsősorban jogszabályban határozhat meg korlátozásokat, addig a legfontosabb gyakorlati jogkörei és utasítási joga a miniszterelnöknek van, míg a közvetlenül alá tartozó belügyminiszter feladata a rendkívüli helyzet gyakorlati kezelése.

A kormány számos jogosítvánnyal élhet, amelyeket a törvény tételesen felsorol.23 A kormány ülésén a kormánytagokon kívül részt vesz még - felszólalási jogosultsággal a parlament elnöke vagy távollétében az alelnöke, a köztársasági elnök megbízott képviselője, valamint az Észt Védelmi Erők parancsnoka ${ }^{24}$ vagy távolléte esetén helyettese. A kormány által hozott rendkívüli jogszabályok a nemzeti tömegtájékoztatásban való közzétételt követôen válnak hatályossá, ám a kihirdetést követő első munkanapon az észt hivatalos lapban is közzé kell tenni azokat. ${ }^{25}$

A rendkívüli helyzet kezeléséért felelős vezető a miniszterelnök vagy távolléte esetén a miniszterelnöki jogköröket gyakorló miniszter. ${ }^{26} \mathrm{~A}$ miniszterelnök jogköre igen széles, utasítást adhat önállóan a belbiztonságért felelős vezetőnek és a kormányzati, valamint önkormányzati szervek vezetőjének a szükségállapotból eredő feladatok kapcsán; felfüggesztheti - a kormány értesítése mellett - a szükségállapot végéig a végrehajtó hatalom tisztségviselőjének státuszát, amennyiben feltételezhető, hogy az adott személy veszélyezteti tevékenységével az ország alkotmányos rendjét (ugyanez vonatkozik a községi és városi tisztségviselőkre is), áthelyezhet kormányzati és önkormányzati tisztviselőket, illetve további feladatokat telepíthet rájuk; korlátozhatja a mozgásszabadságot Észtország egy részén vagy egészén; információk kötelező közzétételét rendelheti el az országos tömegtájékoztatásban; valamint egyéb utasításokat is adhat a kormány felhatalmazására. Tevékenységéről köteles beszámolni a parlamentnek és a kormánynak, a parlament ülésén részt vesz az elnök és a Védelmi Erők parancsnoka vagy az általuk kijelölt személy is. ${ }^{27} \mathrm{~A}$ harmadik felhatalmazottja a különleges jogrendnek a belbiztonságért felelős vezetô, aki a belügyminiszter vagy távolléte esetén a belügyminiszteri hatásköröket gyakorló miniszter. Ôt a törvény egyértelmúen a miniszterelnök alá rendeli, és a rendkívüli helyzet gyakorlati kezelésével bízza meg. Az ő feladata továbbá a kormány által hozott rendkívüli jogszabályok betartatása is. Mindezek érdekében

22 Szükségállapoti tv. 17. szakasz (2) bekezdés, valamint 18. szakasz (3) bekezdés.

23 Szükségállapoti tv. 17. szakasz (1) bekezdés.

24 Nem összekeverendő a föparancsnokkal, aki az alkotmány 78. szakasza értelmében a köztársasági elnök (Dubrovnik, 2009, 25. o.).

25 Szükségállapoti tv. 17. szakasz (3)-(5) bekezdés.

26 Szükségállapoti tv. 18. szakasz (1) bekezdés.

27 Szükségállapoti tv. 18. szakasz. 
együttmúködik a kormányzati szervek és az önkormányzatok vezetőivel, valamint a védelmi erők parancsnokával. A belbiztonságért felelős vezetô utasítási jogkörrel rendelkezik. ${ }^{28}$

A hadsereg bevonható a rendkívüli helyzet kezelésébe a belbiztonságért felelős vezető a hadügyminiszterrel egyeztetett javaslata alapján a kormány döntése szerint, amihez a köztársasági elnök beleegyezése is szükséges. A védelmi erők bevonásáról szóló döntést kormányrendeletként kell formalizálni, és annak tartalmaznia kell a törvényben meghatározott információkat. A kijelölt feladatok ellátása során a védelmi erók parancsnoka vagy az általa meghatározott egység parancsnoka köteles magát alávetni a kormány által meghatározott civil tisztviselőnek. ${ }^{29}$

A rendkívüli helyzet kezeléséért felelős vezetô, illetve a belbiztonságért felelős vezető utasításai három esetben hatályosulnak: ha közzétették azt a hivatalos lapban vagy a nemzeti tömegtájékoztatásban, illetve ha közölték azt annak közvetlen végrehajtójával. ${ }^{30} \mathrm{~A}$ törvény előírja a községi és a városi polgármesterek számára, hogy kövessék a számukra kiadott utasításokat. ${ }^{31}$ Garanciák találhatók a szövegben a miniszterelnök által felfüggesztett tisztségviselők számára: a döntést bíróságon támadhatják meg, valamint az áthelyezett tisztségviselőkkel együtt ők is ugyanabban a bérezésben részesülnek, mint korábban a felfüggesztés, illetve áthelyezés idején. ${ }^{32}$

A szükségállapot vége kapcsán a törvény kizárólag egyetlen esetkört, a hadiállapot bevezetését nevesíti. ${ }^{33}$ Ezenkívül véget érhet a szükségállapot a bevezetésekor megszabott határidő lejártával, illetve a rendkívüli helyzet kezelésével.

A hadiállapotot az alkotmány szerint a köztársasági elnök javaslatára a parlament rendeli el, amely dönt a mozgósításról, demobilizációról, illetve a nemzetközi kötelezettségek teljesítéséről is (a NATO-tagság vonatkozásában). Ennek sajátos esetköre, ha Észtországot külső agresszió éri, ebben az esetben ugyanis a köztársasági elnök egymaga elrendelheti a különleges jogrendet és a mozgósítást. ${ }^{34}$

A honvédelemrôl szóló törvény mind a háború, mind a béke idejére tartalmaz rendelkezéseket. ${ }^{35} \mathrm{~A}$ hadiállapot elrendeléséről szóló rendelkezések első körben megismétlik az alkotmány idevágó passzusait. Ezt követően azonban arról is szó esik, hogy a honvédelmi feladat ellátásával, alapjogot korlátozó intézkedés megállapításával vagy betartásával megbízott hatóság vagy személy köteles az elrendelést követően ezen feladatainak eleget tenni. Abban az esetben, ha az adott tevékenység elengedhetetlen a fenyegetés gyors megelőzése

28 Szükségállapoti tv. 20. szakasz.

29 Szükségállapoti tv. 15. szakasz.

30 Szükségállapoti tv. 21. szakasz.

31 Szükségállapoti tv. 25. szakasz.

32 Szükségállapoti tv. 22-23. szakasz.

33 Szükségállapoti tv. 16. szakasz.

34 Alkotmány 128. szakasz.

35 Honvédelmi tv. 1. szakasz (1) bekezdés. Annak 2015-ös elfogadása előtt külön törvény - a hadiállapoti és a békeidei honvédelmi törvény - foglalkozott a két esetkörrel (Veebel, 2017, 20. o.). 
vagy leküzdése érdekében, akkor az elvégezhető a javaslat benyújtását követôen, mielőtt a parlament elfogadná azt. Amennyiben a törvényhozás nem támogatná a hadiállapot elrendelését, úgy az ezen állapothoz kötődő tevékenységeket be kell fejezni. ${ }^{36}$

A törvény felépítésében a fokozatosság elve jelenik meg, minden megjelenő szint magában foglalja az alacsonyabb szinteken meghatározott feladatokat és jogköröket is, azok nem kerülnek még egyszer felsorolásra. Így a hadiállapot esetén az általános, illetve a fokozott védelmi készültség esetén juttatott eszközök is alkalmazandók.

A törvény értelmében a védekezésért felelős vezető a miniszterelnök. ${ }^{37}$ Ennek megfelelően a törvény igen széles jogosítványokat juttat a számára. ${ }^{38}$ Felhatalmazása alapján hadiállapot esetén a miniszterelnök közigazgatási határozatokat hozhat a védelem megszervezése érdekében, illetve konkrét utasítást adhat a községi vagy városi tanács tagjának, az állami szerv és a helyi önkormányzat vezetőjének, tisztviselőjének és alkalmazottjának, valamint a belbiztonságért felelős miniszternek és a honvédelem megszervezéséért felelős miniszternek a védelem megszervezésével kapcsolatban. ${ }^{39}$ Ezen túlmenően a miniszterelnök hatályon kívül helyezheti a községi és városi önkormányzat, a községi és városi tanács, valamint az állami és önkormányzati hatóság vezetőjének közigazgatási határozatát, és nevükben új közigazgatási határozatot adhat ki, ha ők ezt nem teszik meg vagy nem időben teszik, amennyiben ez veszélyezteti az eredményes védelmet. ${ }^{40} \mathrm{~A}$ miniszterelnök továbbá felhatalmazást kap bizonyos alapjogokat korlátozó intézkedések elrendelésére is. ${ }^{41}$ Fontosságát jelöli az is, hogy a törvény értelmében ő dönt minden más olyan honvédelmi kérdésrôl is, amely az alkotmány vagy törvény alapján nem tartozik más hatóság vagy személy hatáskörébe. ${ }^{42}$

A törvény hadiállapot idejére a kormány egésze számára is fontos jogosultságokat juttat. ${ }^{43} \mathrm{~A}$ kormány is hozhat a miniszterelnökhöz hasonlóan közigazgatási határozatokat, illetve megállapíthat bizonyos alapjogokat korlátozó intézkedéseket. Ezenkívül benyújthatja a parlamentnek a költségvetés módosítását, illetve a kiegészítő költségvetés tervezetét. A kormány utasíthatja a védelmi erőket fegyverszünet kötésére és elrendelésére, illetve maga is dönthet a fegyverszünet és a békekötés kérdésében, amit a parlamentnek is jóvá kell hagynia. Ezeken túl a kormány dönthet valamilyen miniszteri, állami vagy helyi önkormányzati szerv, községi vagy városi tanács által hozott irányelv vagy rendelet alkalmazásának felfüggesztéséről, illetve ennek hatályon kívül helyezéséről is rendelkezhet.

36 Honvédelmi tv. 17. szakasz.

37 Honvédelmi tv. 9. szakasz (1) bekezdés.

38 Honvédelmi tv. 14. szakasz (2) bekezdés, illetve 18. szakasz (2) bekezdés.

39 Honvédelmi tv. 9. szakasz (2)-(3) bekezdés.

40 Honvédelmi tv. 9. szakasz (4) bekezdés.

41 Ezeket a honvédelmi tv. 15., illetve 19-20. szakasza határozza meg.

42 Honvédelmi tv. 18. szakasz (2) bekezdés 2) pont.

43 Honvédelmi tv. 14. szakasz (1) bekezdés, 18. szakasz (2) bekezdés. 
A belbiztonságért felelős miniszter szintén jogosult közigazgatási határozatokat hozni, valamint közvetlen utasításokat adni a hadiállapottal összefüggésben. ${ }^{44}$ Ezeken túl alapjogok korlátozásáról is dönthet.

A hadiállapot utolsó felhatalmazottja az Észt Védelmi Erők (Eesti Kaitsevägi) parancsnoka, illetve az általa felhatalmazott parancsnok, aki szintén jogosult közigazgatási határozatok hozatalára, illetve a belbiztonsági miniszterhez hasonló jogkörben adhat utasításokat. Ezenkívül dönthet fegyverszünet kötéséról, elrendeléséről, illetve annak megszüntetéséről, ha az ellenség nem tartja be a feltételeket. További fontos jogosultság, hogy a védelmi erők parancsnoka a kormány utasítását és rendeletét, miniszter, községi és városi tanács, illetve önkormányzat irányelveit és döntéseit figyelmen kívül hagyhatja, ha ezek közvetlenül akadályozzák a honvédelmet. ${ }^{45} \mathrm{~A}$ törvény ugyanakkor kiköti azt, hogy a miniszterelnök felszólíthatja a védelmi erők parancsnokát, illetve az általa felhatalmazott parancsnokot ezek betartására, amennyiben joggal hihetô az, hogy a rendelkezések betartása nem bír közvetlen hatással a honvédelemre. ${ }^{46} \mathrm{Ez}$ a rendelkezés azt is mutatja, hogy a védelmi erók parancsnoka közvetlenül a miniszterelnöknek van alárendelve. ${ }^{47}$

Az elnök kizárólag a hadiállapot elrendelésénél, illetve megszüntetésénél játszik szerepet, egyébként csak formális jelentősége van. A hadiállapotot a köztársasági elnök javaslatára a törvényhozás szünteti meg. ${ }^{48}$

\subsection{A különleges jogrendre való felkészülést segítő békeidejü szabályok és a kapcsolódó szervezetrendszer}

A Honvédelmi tv. a hadiállapot mellett megkülönbözteti az általános védelmi készültséget, valamint a fokozott védelmi készültséget. Az általános védelmi készültség a mindennapokra jellemző állapot, amikor az egyes szervek és személyek a honvédelemmel összefüggésben kizárólag a rendes feladataikat látják el, illetve felkészülnek a készültségi szint emelésére, valamint a mozgósításra és a demobilizációra. A fokozott védelmi készültség esetén már hárulnak rájuk pluszfeladatok, célja a külső fenyegetéssel szembeni fellépés és az állam múködőképességének a megőrzése. ${ }^{49} \mathrm{~A}$ kormány dönthet úgy, hogy elrendeli a védelmi készültség fokozását vagy az Észtország biztonságát érintő nemzetközi fenyegetettség miatt, vagy nemzetközi katonai múveletben való részvétel céljából. Erről azonnal értesíteni kell a parlamentet és a köztársasági elnököt, előbbinek pedig jóvá kell hagynia a döntést. Jóváhagyás hiányában újra általános védelmi készültség lép életbe. Amennyiben jóváhagyásra

44 Alkotmány 9. szakasz (5) bekezdés.

45 Honvédelmi tv. 14. szakasz (3) bekezdés, 18. szakasz (4) bekezdés.

46 Honvédelmi tv. 14. szakasz (4) bekezdés.

47 Veebel, 2017, 21. o.

48 Honvédelmi tv. 21. szakasz.

49 Honvédelmi tv. 12. szakasz. 
került a védelmi készültség szintjének emelése, úgy a parlament háromhavonta felülvizsgálja azt, és ha csökkent a fenyegetés, megszünteti a fokozott védelmi készültséget. ${ }^{50}$ Maga a kormány is dönthet a védelmi szint csökkentéséról. ${ }^{51} \mathrm{~A}$ fokozott védelmi készültség megszứntével a pluszfeladatokat nem kell tovább ellátni, valamint az alapjog-korlátozó intézkedések is hatályukat vesztik.

Az észt nemzetbiztonsági koncepció átfogó jellegü, amely az ellenálló képességen és az elrettentésen alapul. Észtország honvédelmi stratégiája előírja, hogy a honvédelem már nem korlátozódhat kizárólag a katonai védelemre, emellett hangsúlyt kell helyezni a nem katonai képességekre is. A honvédelmet és a kapcsolódó előkészületeket számos különböző intézmény, valamint a köz- és magánszféra, köztük a civil társadalom feladatainak tekintik. ${ }^{52}$ Ennek a döntésnek történelmi okai vannak, ebben pedig kiemelhető az ország létét folyamatosan veszélyeztető szomszédos Oroszország..$^{33}$ Emellett az ország védelmének garantálásában nagy szerepet játszik a nemzetközi együttmúködés, így különösen a NATOés EU-tagság. ${ }^{54}$ Regionális szinten a három balti állam saját védelmi rendszerének magas szintú összehangolásában jelentős szerepe van a tengerészeti BALTRON és légi megfigyelési BALTNET projekteknek..$^{55} \mathrm{Az}$ ország egyik legfontosabb nemzetbiztonsági dokumentuma a Nemzetbiztonsági Koncepció, ${ }^{56}$ amelyből a legutóbbit 2017-ben fogadták el. A dokumentum meghatározása szerint:

„Az észt biztonságpolitika célja a nemzet függetlenségének és szuverenitásának, a nép és az állam túlélésének, a területi integritásnak, az alkotmányos rendnek és a lakosság biztonságának biztosítása. A biztonságpolitika megvalósításakor Észtország tiszteletben tartja az alapvető jogokat és szabadságokat, és védi az alkotmányos értékeket."

A dokumentum meghatározza a nemzetbiztonsági célokat, alapelveket és a kapcsolódó tevékenységeket. Emellett fontos dokumentum még a honvédelmi stratégia, ${ }^{57}$ amelynek értelmében a honvédelem és a megfelelő előkészületek sok különböző intézmény és személy

50 Honvédelmi tv. 13. szakasz.

51 Honvédelmi tv. 16. szakasz.

52 Veebel-Ploom, 2019, 10. o.

53 Észtországot - a többi balti államhoz hasonlóan - 1918-as függetlenné válása után 22 évvel, 1940-ben annektálta a sztálini Szovjetunió. Az ország az 1991-es függetlenné válása után nem tekintette magát szovjet utódállamnak, hanem az 1940-ben külső fegyveres erőszak hatására megszakadt szuverenitása helyreállításának (Loeber, 1998, 2. o.).

54 Lásd az észt Külügyminisztérium honlapját: https://vm.ee/en/estonia-and-nato (Letöltve: 2020. december 15.) 55 Erről részletesebben lásd a kötet Litvániáról szóló fejezetét.

56 Elérhető: www.riigikantselei.ee/sites/default/files/content-editors/Failid/national_security_concept_2017.pdf (Letöltve: 2020. december 5.).

57 Elérhető: www.kaitseministeerium.ee/sites/default/files/elfinder/article_files/national_defence_strategy.pdf (Letöltve: 2020. december 5.). 
feladatai. A hatékony honvédelmet mind a katonai, mind a nem katonai képességek, az állami és a magánszektor, valamint a civil társadalom erőforrásai és tevékenységei együttesen biztosítják. ${ }^{58} \mathrm{~A}$ honvédelmi stratégia alapul szolgál a kormány által összeállított honvédelmi fejlesztési tervnek. Ennek implementálására hivatott a honvédelmi akcióterv, amelyet a hadügyminiszter állít össze négy évre, évente felülvizsgálva azt. Végül az utolsó fontos dokumentum a nemzeti honvédelmi terv, amely a honvédelmi stratégiában megfogalmazott célok mentén tartalmazza a honvédelmi feladatok ellátását, a rendelkezésre álló katonai képességek felhasználásával. Ezt a védelmi erők parancsnoka évente állítja össze, a hadügyminiszter jóváhagyásával..$^{59}$
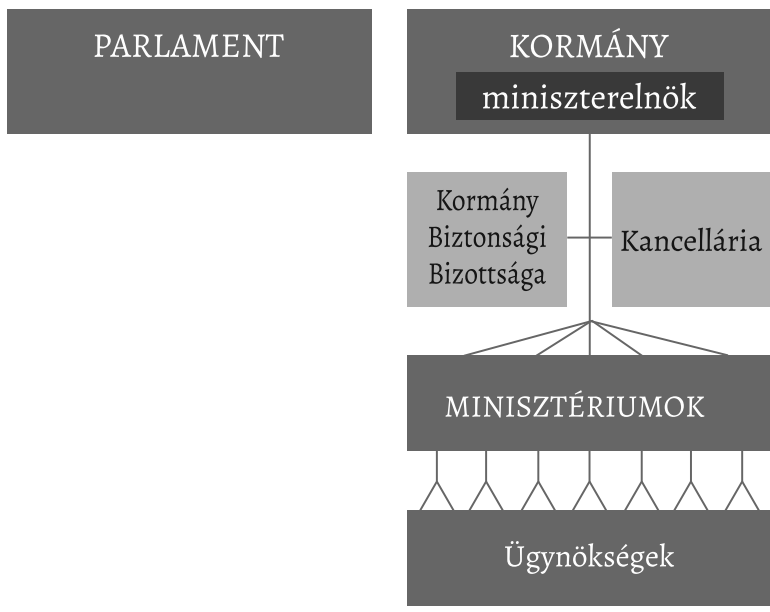

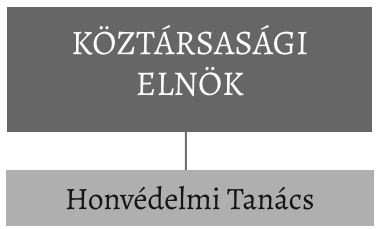

Honvédelmi Tanács

\begin{abstract}
6. ábra
Az észt honvédelem irányitási struktúrája

Forrás: a szerző összeállitása az észt Honvédelmi Minisztérium honlapja alapján ${ }^{60}$
\end{abstract}

$\mathrm{Az}$ észt stratégiai döntéshozatal három legfontosabb szerve a Honvédelmi Tanács, a kormány Biztonsági Bizottsága, illetve a kormány Válságbizottsága, amelyek tagsága és funkciói között nagy átfedések találhatók. ${ }^{61} \mathrm{~A}$ Válságbizottságnak a szükségállapottal, a Biztonsági Bizottságnak pedig a honvédelemmel kapcsolatos kérdésekben van nagy jelentősége. A Honvédelmi Tanács mind a két kérdéskörben érintett.

58 Elérhető: www.riigikantselei.ee/en/co-ordination-security-and-national-defence (Letöltve: 2020 . december 5.). 59 Elérhető: www.kaitseministeerium.ee/en/objectives-activities/basic-national-defence-documents (Letöltve: 2020. december 5.).

60 Elérhető: www.riigikantselei.ee/en/co-ordination-security-and-national-defence (Letöltve: 2020. december 10.).

61 Veebel, 2017, 12. o. 
A Honvédelmi tv. értelmében a kormány Biztonsági Bizottsága (Vabariigi Valitsuse julgeolekukomisjon) koordinálja a végrehajtó hatalom szerveinek tevékenységét a honvédelem tervezése, fejlesztése és megszervezése során. ${ }^{62} \mathrm{~A}$ bizottság tagjai a honvédelemmel kapcsolatos területekért felelős miniszterek (a miniszterelnök, az igazságügyi miniszter, a külügyminiszter, a pénzügyminiszter, a hadügyminiszter és a belügyminiszter). A bizottság további feladatait a biztonsági hatóságokról szóló törvény határozza meg. ${ }^{63} \mathrm{Ez}$ alapján koordinálja a biztonsági hatóságok tevékenységét, elemzi és értékeli az állam biztonsági helyzetét, meghatározza az állam igényét a biztonsággal kapcsolatos információkra, valamint más, törvény által meghatározott feladatokat is ellát. ${ }^{64}$

A nemzetbiztonsággal kapcsolatos kormányzati szakpolitika alakításában a kancellária (Riigikantselei) játssza a legfontosabb szerepet: tanácsot ad a miniszterelnöknek a nemzetbiztonsággal összefüggésben, megszervezi kormány Biztonsági Bizottságának munkáját, valamint irányítja a nemzetbiztonsági és a honvédelmi irányítás összehangolását. ${ }^{65} \mathrm{~A}$ kancellária emellett a szakpolitikai tartalom legfőbb szolgáltatója a bizottság számára, az észt biztonsági politika irányításáért felelős legmagasabb testület, ${ }^{66}$ ennek megfelelően elkészíti a nemzetbiztonsági koncepciót, illetve a honvédelmi stratégia alapján koordinálja a honvédelmi előkészületeket. ${ }^{67}$

A kormány Válságbizottsága létrehozásáról a Veszélyhelyzeti tv. rendelkezik, amely a kormányzati szint mellett négy regionális, valamint helyi válságbizottságok létrehozásáról is rendelkezik. A Válságbizottság munkáját a Belügyminisztérium szervezi meg, mint a válságkezelésért felelős fő szakpolitikai szerv. ${ }^{68}$ Jogállásával és múködésével külön kormányrendelet foglalkozik. ${ }^{69}$ Elnöke a belügyminiszter, összesen 21 taggal működik, köztük kilenc államtitkár és nyolc magas rangú tisztviselő található. Feladata a válságkezelési feladatok összehangolása, ${ }^{70}$ illetve az ország alkotmányos rendjét érő fenyegetés kapcsán kidolgozza az állami politikát és a cselekvési terveket; elemzi az információkat és azokat bemutatja a miniszterelnöknek a fenyegetésekkel kapcsolatban; véleményt nyilvánít a kormány számára a fenyegetést megelőző helyzetről, a veszély jellemzőiről, mértékéről és megszüntetéséről, valamint a szükségállapot kihirdetésének szükségességéről; illetve véleményt nyilvánít a kormánynak és a rendkívüli helyzet kezeléséért felelős vezetőnek a szükségállapoti intézkedések végrehajtásáról. ${ }^{11}$

62 Honvédelmi tv. 4. szakasz (1) bekezdés 1) pont.

63 Biztonsági hatóságokról szóló törvény (Julgeolekuasutuste seadus 2000. 12. 20.).

64 A biztonsági hatóságokról szóló törvény 10. szakasz.

65 Elérhető: www.riigikantselei.ee/en/government-office (Letöltve: 2020 . december 5.).

66 Veebel-Ploom, 2019, 16. o.

67 Elérhető:www.riigikantselei.ee/en/co-ordination-security-and-national-defence (Letöltve: 2020. december 15. )

68 Veszélyhelyzeti tv. 7. szakasz.

69 A kormány válságbizottságának jogállásáról szóló kormányrendelet (Vabariigi Valitsuse kriisikomisjoni põ-

himäärus 2017. 06. 22. nr 111.).

70 Veszélyhelyzeti tv. 4. szakasz.

71 Szükségállapoti tv. 8. szakasz. 
Végül szót kell még ejteni a Honvédelmi Tanácsról is, amely a köztársasági elnök mellett múködő tanácsadó szerv, és mint a neve is mutatja, elsősorban a fontos kérdések honvédelmi aspektusait vizsgálja, és véleményt nyilvánít ezek kapcsán. Tagjai a parlament házelnöke, a miniszterelnök, a parlament Honvédelmi Bizottságának és a Külügyi Bizottságának elnöke, a külügyminiszer, a hadügyminiszter, a pénzügyminiszter, a belügyminiszter, az igazságügyi miniszter, a gazdasági miniszter és a védelmi erők parancsnoka. A jogállását és múkködését köztársasági elnöki rendelet tartalmazza. ${ }^{72}$

\subsection{A válságkezelésre vonatkozó szabályok}

A válságkezeléssel kapcsolatos szabályokat a Veszélyhelyzeti tv. tartalmazza, amelyet 2017-ben fogadtak el, és ugyanezen év július 1-jén lépett hatályba. Elfogadásának kifejezett célja volt, hogy az eddig szektoriálisan, széttöredezetten szabályozott esetkörök kezelését egységesítse. Hatálya a katasztrófákon túl kiterjed az egyes alapvető szolgáltatások leállásának kezelésére is. ${ }^{73}$

A törvény a válságkezelés jogi alapját biztosítja, ideértve a veszélyhelyzetre való felkészülést és annak kezelését, valamint az alapvető szolgáltatások nyújtása folytonosságának biztosítását. Ezenkívül tartalmazza a válsághelyzet szabályait és a fegyveres erők válságkezelésbe való bevonásának szabályait is. A törvényt alkalmazni kell a szükségállapot, fokozott védelmi készültség és hadiállapot idején is, amennyiben a Szükségállapoti tv. vagy a Honvédelmi tv. másként nem rendelkezik. A törvény nem vonatkozik a nemzetbiztonságot vagy az alkotmányos rendet érintő fenyegetésekre való felkészülésre. ${ }^{74}$

A válsághelyzet a törvény meghatározása szerint „olyan esemény vagy eseménylánc vagy létfontosságú szolgáltatás nyújtásának megszakadása, amely sok ember életét vagy egészségét veszélyezteti, jelentős anyagi károkat, jelentős környezeti károkat vagy súlyos és kiterjedt zavarokat okoz a létfontosságú szolgáltatások nyújtásának folyamatosságában". Az ilyen helyzet megoldásához számos hatóság vagy személy megfelelően koordinált tevékenysége szükséges, a szokásostól eltérő utasítási rendszerben, valamint a szokásosnál több személyt és eszközt igényel. ${ }^{75}$

A törvény meghatározza az alapvető szolgáltatás fogalmát is, amely olyan szolgáltatás, amelynek döntő befolyása van a társadalom múködésére, és amelynek megszakítása közvetlen veszélyt jelent az emberek életére vagy egészségére, vagy egy másik létfontosságú

72 Elérhető: www.president.ee/en/president/institutions/1031-national-defence-council/5262-national-defencecouncil/layout-institution.html (Letöltve: 2020. december 15.).

73 Elérhető: www.siseministeerium.ee/en/news/emergency-act-entered-force-1-july (Letöltve: 2020. december 15.).

74 Veszélyhelyzeti tv. 1. szakasz.

75 Veszélyhelyzeti tv. 2. szakasz (1) bekezdés. 
vagy közérdekú szolgáltatás müködésére. ${ }^{76} \mathrm{Az}$ alapvető szolgáltatások körét a törvény részletesen is tartalmazza. ${ }^{77}$ Ezek:

— áramszolgáltatás;

- földgázellátás;

— üzemanyag-ellátás;

— a nemzeti és helyi utak múködőképességének biztosítása;

- telefonszolgáltatás;

— mobiltelefon-szolgáltatás;

— adatátviteli szolgáltatás;

- digitális azonosítás és digitális aláírás;

— fizetési szolgáltatások;

- készpénzforgalom;

- távfưtés;

— vízellátás és csatornázás.

Észtországban 45 szolgáltatást tekintenek alapvetőnek. Ezeket összesen 167 szolgáltató biztosítja: 131 állami és magánvállalkozás, 19 alapítvány, 16 állami ügynökség és egy önkormányzati intézmény. ${ }^{78}$

A törvény úgy rendelkezik, hogy az alapvető szolgáltatások folyamatosságát biztosító hatóságok - amelyek lehetnek minisztériumok, pénzügyeknél a nemzeti bank, illetve önkormányzatok - összehangolják az alapvető szolgáltatás folyamatosságának biztosítását, tanácsot adnak az alapvető szolgáltatások nyúitóinak, felügyelik az alapvetô szolgáltatások folytonosságát, jóváhagyják az alapvető szolgáltatást nyújtó szolgáltatók folytonossági kockázatelemzéseit és terveit, valamint koordinálják a válsághelyzet megoldását, elkészítik a válsághelyzeti reagálási tervet, és megszervezik a kockázatkommunikációt és a válságkezelési gyakorlatokat. ${ }^{79}$

A törvény előírja kormányzati, regionális, illetve helyi válságbizottságok felállítását, amelyek különböző szinteken koordinálják a válságkezelést, illetve az eggyel magasabb szint számára éves jelentéseket készítenek munkájukról. ${ }^{80} \mathrm{~A}$ válságkezelés koordinálásában fontos szerep jut még a Belügyminisztériumnak, amely kidolgozza a nemzeti válságkezelési politikát és megtervezi annak végrehajtását, tanácsot ad a hatóságoknak és irányítja tevékenységüket a válságkezelés szervezésében, valamint felügyeli a törvény által a hatóságokra ruházott feladatok teljesítését. ${ }^{81}$

A törvény külön fejezetben foglalkozik a válsághelyzetre való felkészüléssel, annak megelőzésével, illetve kezelésével. A kormány külön rendeletben határozza meg azokat az ese-

76 Veszélyhelyzeti tv. 2. szakasz (4) bekezdés.

77 Veszélyhelyzeti tv. 36. szakasz.

78 Elérhető: www.siseministeerium.ee/en/activities/crisis-management (Letöltve: 2020. december 15.).

79 Veszélyhelyzeti tv. 37. szakasz.

80 Veszélyhelyzeti tv. 4-6. szakasz.

81 Veszélyhelyzeti tv. 7. szakasz. 
ményeket, amelyek válsághelyzethez vezetnek, és amelyek esetén kockázatelemzésnek van helye. A kockázatelemzés egy dokumentum, amely a válsághelyzet bekövetkezésének valószínűségét és feltehető hatásait tartalmazza. Elvégzésének feltételeit, illetve az előkészítés folyamatát az adott ágazatért felelős miniszter rendeletben határozza meg. ${ }^{82} \mathrm{~A}$ törvény elő́rja természetes személyek számára, hogy kötelesek értesíteni a hatóságokat egy válsághelyzet bekövetkeztéről, kivéve, ha feltehető, hogy arról már értesültek. ${ }^{{ }^{3}} \mathrm{~A}$ válsághelyzetekre való felkészülésben nagy szerepe van az elhárítási terveknek: a kormány külön rendeletben határozza meg azon válsághelyzeteket, amelyek kapcsán tervet kell készíteni, és kijelöli erre a megfelelő hatóságot. Ezeken túl az alapvetô szolgáltatások nyújtásának folytonosságáért felelős hatóságok is terveket készítenek arra az esetre, ha az adott alapvető szolgáltatás nyújtása megszakadna. ${ }^{84} \mathrm{~A}$ fejezet ezenkívül rendelkezik még a tömeges evakuációról, illetve a válságkezelési gyakorlatok tartásáról. ${ }^{85}$

A válsághelyzet kezelésének második, sokkal súlyosabb szintje a veszélyhelyzet, amelynek szabályai a törvény külön fejezetében kaptak helyet. A kormány természeti katasztrófa, katasztrófa vagy fertőző betegség okozta válsághelyzet kezelésére hirdetheti ezt ki, ha annak kezelése nem lenne lehetséges a veszélyhelyzeti eszközök alkalmazása nélkül. A törvény meghatározása szerint a katasztrófa emberi tevékenység okozta nagyszabású baleset, veszélyhelyzet vagy más hasonló hatású helyzet, ideértve az alapvető szolgáltatások nyújtásának súlyos következményekkel járó vagy elhúzódó megszakadását. ${ }^{86} \mathrm{~A}$ fertőző betegségeket külön törvény határozza meg. ${ }^{87}$

A veszélyhelyzet bevezetéséról a kormány dönt, az ország egész területén vagy annak egy részén. ${ }^{88} \mathrm{Az}$ ezzel kapcsolatos kormányrendeletnek tartalmaznia kell a veszélyhelyzet bevezetését, annak okát, az elrendelés területi hatályát, a veszélyhelyzet kezelésének fejét és minden egyéb fontos tényezôt.$^{89} \mathrm{~A}$ veszélyhelyzetet elrendelő, illetve megszüntető utasítást késedelem nélkül közzé kell tenni a nemzeti médiában, illetve egy napon belül Észtország hivatalos lapjában..$^{90} \mathrm{~A}$ veszélyhelyzet megszüntetéséról a kormány dönt. ${ }^{91}$

A veszélyhelyzet kezelésének feje a kormány által kijelölt miniszter, aki alárendelt a kormánynak, és a veszélyhelyzet kezelésén tevékenykedik. Utasítást adhat ezzel összefüggésben

82 Veszélyhelyzeti tv. 9. szakasz.

83 Veszélyhelyzeti tv. 12. szakasz (1) bekezdés.

84 Veszélyhelyzeti tv. 15. szakasz.

85 Veszélyhelyzeti tv. 16-18. szakasz.

86 Veszélyhelyzeti tv. 19. szakasz.

87 A fertőző betegségek megelőzéséről és csökkentéséről szóló törvény (Nakkushaiguste ennetamise ja tõrje seadus 2003. 02. 12.) 2. szakasza tartalmazza a definíciót, a törvény különbséget tesz fertőző betegség és súlyosan veszélyes fertőző betegség (például kolera, sárgaláz, pestis) között.

88 Veszélyhelyzeti tv. 20. szakasz.

89 Veszélyhelyzeti tv. 21. szakasz.

90 Veszélyhelyzeti tv. 23. szakasz.

91 Veszélyhelyzeti tv. 22. szakasz. 
az elhárítási munka vezetőjének, hatóságoknak, személyeknek. ${ }^{92}$ Ha a veszélyhelyzet során bevezetésre kerül a szükségállapot, a veszélyhelyzet kezelésének feje a rendkívüli állapot kezeléséért felelős vezető - vagyis a miniszterelnök - alárendeltségébe kerül.93

A veszélyhelyzet megoldásában a védelmi erők bevonhatók a veszélyhelyzeti munka elvégzésébe, illetve a forgalom szabályozásába és a biztonság biztosításába. ${ }^{94} \mathrm{~A}$ veszélyhelyzet és válsághelyzet során tevékenységet kifejtő nem katonai szervezetek múkködését és munkáját a mentési törvény szabályozza részletesen. ${ }^{95}$

\section{Az alapjogok korlátozására vonatkozó szabályok különleges jogrend idején}

Észtországban az alapjog-korlátozás kapcsán a negatív listás megoldás érvényesül, ${ }^{96}$ vagyis az alkotmány azon alapjogok listáját határozza meg, amelyek korlátozhatatlanok a különleges jogrend idején. ${ }^{97}$ Ezt a tiltást a Honvédelmi tv. is megismétli. ${ }^{98}$

Az alkotmány mindemellett kimondja, hogy háborús helyzetben, illetve szükségállapot idején - a közrend és a nemzetbiztonság érdekében - az alapvetó jogok és szabadságok korlátozhatók, a kötelezettségek pedig kikényszeríthetők. Minderre csak törvény által meghatározott feltételek között, illetve eljárás során kerülhet sor. Az alapjog-korlátozó döntések minden esetben megtámadhatók közigazgatási bíróság előtt.99

Fontos kiemelni, hogy az észt alkotmány egy külön választási klauzulát is tartalmaz, amely kimondja, hogy a parlament, a köztársasági elnök és a helyi önkormányzatok megbízatása háborús helyzet, illetve szükségállapot időszakában nem járhat le. Az ilyen helyzetben lejáró megbízatás a háborús helyzet vagy szükségállapot végét követő három hónappal meghosszabbodik, és a választást ebben a három hónapos időszakban kell megtartani. ${ }^{100}$

92 Veszélyhelyzeti tv. 24. szakasz.

93 Szükségállapoti tv. 18. szakasz (7) bekezdés.

94 Veszélyhelyzeti tv. 34. szakasz.

95 Mentési törvény (Päästeseadus 2010. 05. 05.).

96 Gross, 2004, 21. o.

$97 \mathrm{Az}$ alkotmány 130. szakasza alapján a nem korlátozható alapjogok listája a következő: az állampolgársághoz való jog; jogegyenlőség és diszkrimináció tilalma; jogvédelem és konzuli védelem; az állami szervek alapjogvédelmi kötelezettsége; alapvető jogok sérelme esetén a bírósághoz fordulás joga; élethez való jog; a becsülethez és a jó hírnévhez fúződő jogok; embertelen bánásmód tilalma; személyi szabadság büntetőjogi célú korlátozásának lehetôsége; a büntetőjogi és büntetőeljárás-jogi garanciák; egyes polgári eljárásjogi garanciák; a jogtalan károkozásért kártalanításhoz való jog; a család védelméhez való jog; az egészség védelméhez való jog; észt polgárok jogalap nélküli kiadatásának tilalma; a gondolat-, lelkiismereti és vallásszabadság; a kisebbségi identitáshoz való jog; valamint a hivatalos ügyintézés során az észt nyelv használatához való jog. 98 Honvédelmi tv. 19. szakasz.

99 Maruste, 2020.

100 Alkotmány 131. szakasz. 
Mind a Honvédelmi tv., mind a Szükségállapoti tv. és a Veszélyhelyzeti tv. tartalmaz rendelkezéseket az alapjogok korlátozása vonatkozásában. A Szükségállapoti tv. alapján például felfüggeszthetô a nonprofit szervezetek - ideértve a politikai pártokat és a szakszervezeteket is - múködése a szükségállapot idejére, amennyiben tevékenységük veszélyezteti Észtország alkotmányos rendjét. Az ezzel kapcsolatos javaslatot a miniszterelnök nyújtja be a Legfelsőbb Bíróságnak, amely dönt a kérdésben..$^{101} \mathrm{~A}$ kormány és a belbiztonságért felelős vezető is dönthet bizonyos alapjog-korlátozó intézkedések bevezetéséről. A kormány felfüggeszthet jogszabályokat, illetve azok alkalmazását, megtilthatja az országba lépést vagy annak elhagyását, kijárási tilalmat rendelhet el, bizonyos információk továbbítását megtilthatja, illetve megtilthatja bizonyos médiatermékek megjelenését, megtilthatja a sztrájkokat és az összejöveteleket, bizonyos termékek eladása kapcsán intézkedéseket hozhat (például jegyrendszer bevezetése). ${ }^{102} \mathrm{~A}$ belbiztonságért felelős vezető például korlátozhatja a közlekedést, a kijárási tilalom idején dokumentumok ellenőrzését szabhatja meg, dönthet személyek lakhelyének megváltoztatásáról, korlátozhatja a küldemények és üzenetek bizalmasságát, elkobozhatja a fegyvereket, a mérgező és robbanóanyagokat stb. ${ }^{103}$ Hadiállapot esetén a kormány hozhat döntést az alapjogok korlátozásáról. Így például korlátozható a gyülekezési jog, megtilthatók a sztrájkok, korlátozható bizonyos ingóságok kereskedelme, valamint a kommunikációs eszközök igénybevétele és a tömegtájékoztatásban közzétett információk köre, illetve bizonyos sajtótermékek megjelenése megtiltható. ${ }^{104}$ Ezeken túl a fokozott védelmi készültség idején elrendelhető korlátozások hadiállapot idején is alkalmazhatók.

Fontos megjegyezni, hogy a különleges jogrendnek nem minősülő felhatalmazás esetköreiben is lehetőség van alapjogok korlátozására. A fokozott védelmi készültség esetén megtilthatja az ország elhagyását azon személyek számára, akik szolgálati vagy munkaviszonyuk alapján munkakötelezettséggel bírnak. A fokozott készültség idején a személyekre további honvédelmi kötelezettségek róhatók. ${ }^{105}$ Veszélyhelyzet esetén a Veszélyhelyzeti tv. számos eszköz alkalmazását teszi lehetôvé, így elrendelhető munkakötelezettség, bizonyos ingóságok (üzemanyag, élelmiszer, gyógyszerek, más fogyócikkek) kisajátítása, bizonyos nem ingó eszközök, ingatlanok kormányzati használatba bocsátásra való kötelezettség, helyszíni válsághelyzeti munka elvégzésére való kötelezés, tartózkodási tilalom és a mozgásszabadság egyéb korlátozásai, nyilvános gyưlések és események korlátozása, valamint közigazgatási kényszerítő intézkedések elóírása és alkalmazása. ${ }^{106}$

A veszélyhelyzet esetén az alapjog-korlátozás alapja a Veszélyhelyzeti tv. felhatalmazása, amely ugyanakkor nem minősül különleges jogrendnek, és az alkotmány a 130. szakaszában

101 Szükségállapoti tv. 19. szakasz.

102 Szükségállapoti tv. 17. szakasz (1) bekezdés.

103 Szükségállapoti tv. 20. szakasz.

104 Honvédelmi tv. 20. szakasz.

105 Honvédelmi tv. 15. szakasz.

106 Veszélyhelyzeti tv. 26-33. szakasz. 
sem nevesíti mint olyan esetkört, amikor az alapvető jogok korlátozhatók. Maruste véleménye szerint a törvény elfogadásával átadta alkotmányos funkcióját a végrehajtó hatalomnak. Ráadásul a válsághelyzeti rendeletek és utasítások így magát az alkotmányt írják felül, ami súlyos hiányosság, és teljesen szembemegy a jogszabályi hierarchiával. ${ }^{107}$

\section{A koronavírus-járványra adott állami reakció}

A koronavírus-járvány kapcsán nem került sor különleges jogrend bevezetésére, mivel a szükségállapot elrendeléséhez szükséges feltételek nem álltak fenn. Járványhelyzetek kapcsán a Veszélyhelyzeti tv. rendelkezései irányadók, és annak alapján március 12-én bevezetésre került a veszélyhelyzet, első alkalommal a törvény 2017-es elfogadása óta. A veszélyhelyzet bevezetését a kormány mellett müködő állandó Válságbizottság javasolta, és eredetileg május 1-jéig került bevezetésre. ${ }^{108} \mathrm{~A}$ veszélyhelyzetet a kormány később meghoszszabbította május 17-ig. ${ }^{109}$ (Több sajtótermékben, illetve hivatalos dokumentumban is található a bevezetett intézkedés megnevezésével kapcsolatosan tévedés, amely valószínúleg ezek angol nyelvứ változatának hasonlóságából ered. ${ }^{110}$

A rendelkezések az élet számos területére kiterjedtek, így például elrendelték az oktatási és kulturális intézmények bezárását és a kulturális, oktatási és sporttevékenységek törlését; a szociális ellátóintézményekben és kórházakban látogatási tilalmat vezettek be, akárcsak a börtönökben; a mozgás szabadságának korlátozására is sor került, így a szigetek és a szárazföld között közlekedő hajókon; illetve ideiglenes ellenőrzési intézkedések is bevezetésre kerültek a határon (ideértve a veszélyesnek ítélt országokból érkező személyek két hétre történő karanténba zárását); valamint a mozgáskorlátozásra és a szabadidő eltöltésére vonatkozó további korlátozások is megállapításra kerültek. ${ }^{111} \mathrm{Az}$ ország március 20 -án az emberi jogok európai egyezménye 15. szakasza szerint tájékoztatást küldött az Európa Tanácsnak arról, hogy felfüggeszti az egyezmény egyes részeinek alkalmazását a pandémia idejére. ${ }^{112} \mathrm{~A}$ felfüggesztés visszavonására a veszélyhelyzet végével, május 18-án került sor.

107 Maruste, 2020.

108 Elérhető: www.valitsus.ee/en/news/government-declared-emergency-situation-estonia-until-1-may (Letöltve: 2020 . december 15.).

109 Elérhető:www.valitsus.ee/en/news/special-notice-government-has-extended-emergency-situation-estoniauntil-may-17 (Letöltve: 2020. december 15.); Venice Commission, 2020, 16. 0. 50. pont.

110 Lásd például a Velencei Bizottság kapcsolódó anyagát, ahol szükségállapot bevezetéséről írnak a járványkezeléssel összefüggésben, ugyanakkor a kapcsolódó lábjegyzetben már helyesen jelölik a jogintézményt (Venice Commission, 2020, 10. 0.35. pont).

111 Elérhető: www.europarl.europa.eu/RegData/etudes/BRIE/2020/651914/EPRS_BRI(2020)651914_EN.pdf (Letöltve: 2020 . december 15.).

112 Venice Commission, 2020, 6. o. 16. pont. 
Az ország hasonló okból tájékoztatást küldött az ENSZ-nek a Polgári és Politikai Jogok Nemzetközi Egyezségokmánya 4. szakasza alapján az egyezménytől való eltérésről. ${ }^{113}$

A koronavírus során bevezetett veszélyhelyzet tapasztalatai komoly aggályokat vetnek fel a jogintézmény kapcsán. Először is azáltal, hogy a parlament teljes egészében kimaradt annak bevezetéséből, hiszen a törvény ezt nem is teszi szükségessé. A parlament bevonására kizárólag akkor került sor, amikor a veszélyhelyzet bevezetését követően néhány héttel javaslatot nyújtottak be a parlamenthez a veszélyhelyzet gyakorlati alkalmazásához kapcsolódó törvények módosítása, illetve kiegészítő költségvetés elfogadása végett. A 33 törvényt módosító javaslatcsomagot 54:40 szavazatarányban elfogadta a törvényhozás. Ez három különböző típusú módosítással operált: először is, a különféle engedélyek érvényességével, valamint a különféle típusú eljárások időtartamával és határidejével kapcsolatos kivételek a vészhelyzet idejére, másodsorban a különböző hatóságok és személyek hatáskörének és feladatainak kiterjesztését célzó kivételek a vészhelyzet idejére, harmadszor a vészhelyzet miatt eredetileg szükséges módosítások, amelyek azonban lényegében állandó jellegűek. ${ }^{114}$ A parlament kísérletet tett a Veszélyhelyzeti tv. módosítására is, ám ez nem járt sikerrel. ${ }^{115}$

A veszélyhelyzet bevezetése ugyan formálisan jogszerú volt a Veszélyhelyzeti tv. rendelkezései alapján, azonban az a tény, hogy a parlament kihagyható a folyamatokból, nehezen egyeztethető össze a parlamentáris demokrácia alkotmányos alapelveivel. Nehezen magyarázható, hogy a komoly alapjogi korlátozások bevezetése miért nem igényli a parlament hozzájárulását semmilyen módon. A törvény alapján a kormány rendeleti úton, utasításokkal vezette az országot, amelyek komolyan kihatottak a társadalom egészére, a gazdaságra és az alapjogokra. A törvény értelmében a rendeletek végrehajtását és azok törvényi megfelelőségét maga a kormány vizsgálja. Ugyan közigazgatási bíróság előtt megtámadhatók az alapjogokat sértő rendelkezések, ezeket csak utólagosan vizsgálja a bíróság rendes eljárásban. ${ }^{116}$ Fontos ugyanakkor megjegyezni, hogy ezek a fejlemények nem vezettek autoriter törekvésekre a kormány részérôl, még ha a demokrácia alapelveit sértették is. A kritikák között volt említhető az is, hogy az egyes veszélyhelyzeti rendelkezések egyáltalán nem tartalmaztak lejárati idôt. ${ }^{117}$

A veszélyhelyzet május 17-i végével a sokkal enyhébb válsághelyzeti állapot került bevezetésre, amely a kézirat lezárásának időpontjában is fennállt. ${ }^{118}$

113 Venice Commission, 2020, 6. o. 16. pont. Lásd még az észt külügyminisztérium honlapját: https://vm.ee/en/ obligations-ministry-foreign-affairs-inform-international-organisations-emergency-situation-measures (Letöltve: 2020. december 15.).

114 Elérhetô:https://m.riigikogu.ee/en/sitting-reviews/riigikogu-passed-act-relating-implementation-emergencysituation/ (Letöltve: 2020. december 15.).

115 A Veszélyhelyzeti tv. módosítása kapcsán a parlamenti vitában az egyik párt két, egymással is összefüggő módosítási javaslatot is benyújtott, ám ezek közül csak az egyiket fogadta el a törvényhozás, ami komoly értelmezési és gyakorlati problémákhoz vezethet. Elérhető: https://news.err.ee/1088740/riigikogu-vote-leavescrisis-situation-law-defective (Letöltve: 2020. december 15.).

116 Maruste, 2020.

117 Makarychev-Romashko, 2021.

118 Az intézkedések köréról lásd:www.riigiteataja.ee/en/eli/518122020003/consolide (Letöltve: 2020. december 15.). 


\section{A különleges jogrend a gyakorlatban: viták és kihívások}

Észtország a függetlenség 1991-es kikiáltása óta egyszer sem alkalmazta a különleges jogrendet. Az ország alkotmánya a függetlenség egyik garanciájaként tartalmazza a rendelkezéseket, ${ }^{119}$ és több olyan krízis is bekövetkezett, amely indokolttá tette volna alkalmazását, erre mégsem került sor. Akárcsak a szükségessége, a legvégső eszközként való alkalmazása és garanciákkal történő körülbástyázása is történelmi tapasztalatokon alapul. ${ }^{120}$ Alkalmazásának lehetősége először 1992-ben merült fel a gazdasági nehézségek kezelésére, különösen a fővárost sújtó élelmiszerhiány miatt. Végül a kormány nem tudta keresztülvinni akaratát és megbukott, az ezt követő szakértői kormány pedig elzárkózott a különleges jogrend bevezetésétől. ${ }^{121}$

2007. április 27. és május 18. között Észtországot igen komoly és kiterjedt, orosz hátterú kibertámadás érte, miután egy világháborús szovjet hősi emlékmú eltávolításáról döntöttek, és ez súlyos konfliktusokhoz vezetett az ország orosz ajkú lakosságával. Bár a támadás számos állami funkció múködését akadályozta vagy lehetetlenítette el, különleges jogrend bevezetésére mégsem került sor. ${ }^{122} \mathrm{~A}$ később elfogadott Veszélyhelyzeti tv. alapján azonban egy hasonló súlyú kibertámadás esetén akár veszélyhelyzet is elrendelhetổ lenne, hiszen az megfelel a „katasztrófa” törvényi fogalmi felételeinek. 2011-ben a kockázatelemzésen a kiterjedt kibertámadás „nagyon magas”, míg 2013-ban „magas” veszélyességi besorolást kapott. ${ }^{123}$

Az ország igen komolyan veszi a digitális veszélyeket. 2017-ben a személyi igazolványokban található okoskártyachipekben fedeztek fel sérülékenységet, amelyeket ekkoriban már a lakosság fele használt. A kártyákban lévő chipek segítségével lehetett az állami e-szolgáltatásokat igénybe venni, elektronikus aláirást készíteni és akár szavazni is. A kormány döntése alapján a szolgáltatást nyújtó jogi személy korlátozta a személyi igazolványok tanúsítványait tartalmazó nyilvános adatbázishoz való hozzáférést, amelyhez így csak a cég szerződéses partnerei férhettek hozzá. Mivel ezek közérdekú információk, semmiféle jogi alapja nem volt ennek a korlátozásnak, azt csak a szükségállapot bevezetése teremtette volna meg. A szolgáltató vissza kívánta volna vonni az érintett sérülékeny tanúsítványokat, ám ez

119 Loeber, 1998, 6. o.

120 Az észt függetlenség 1918-as kikiáltását követően állandósult a részleges szükségállapot az országban. 1933ban a kormány a szélsőjobboldali Észt Szabadságharc Résztvevőinek Uniója (a Vaps Mozgalom) hatalomátvételétől tartva szükségállapotot vezetett be. Miután a Vaps Mozgalom által benyújtott alkotmánytervezetet népszavazáson elfogadták, a kormány lemondott, és Konstantin Päts alakított ideiglenes kormányt. Päts 1934-ben az új alkotmány felhatalmazásai alapján alkotmányos puccsot hajtott végre, és betiltotta a Vaps Mozgalmat, illetve az összes pártot. Päts elnök idején új szükségállapoti törvényt fogadtak el 1938-ban, ami nélkülözte a szükségállapot fenntartásának bármilyen objektív feltételét, és a kormányzás egyfajta általános eszközévé vált, amelyet a politikai elit hatalmának fenntartása érdekében alkalmaztak. Päts egyeduralma az ország 1940-es szovjet megszállásáig megmaradt, azt követően pedig a szovjetbarát kormány használta azt saját céljaira (Kenkmann, 2018; Valge, 2011).

121 Smith, 2001, 77. o.; Lane et al., 2013, 77. o.

122 Elérhető: https://ccdcoe.org/uploads/2018/10/Ottis2008_AnalysisOf2007FromTheInformationWarfarePersp ective.pdf (Letöltve: 2020 . december 15.).

123 Osula, 2015. 
az észt e-állam teljes összeomlásához vezetett volna. A kormány vizsgálta a Veszélyhelyzeti tv. alkalmazásának a lehetőségét: mivel a szolgáltató alapvető szolgáltatást nyújtónak minősül a törvény szerint, így kötelezhetô a szolgáltatás folyamatos nyújtására. Ugyanakkor ez a fajta jogi érvelés nem állja meg a helyét: a cég nem szüntette volna meg a bizalmi szolgáltatások nyújtását, sốt, valójában az ezek nyújtásával kapcsolatos kötelezettségeinek tett volna eleget azzal, ha a sérülékeny tanúsítványokat visszavonja. ${ }^{124}$

$\mathrm{Az}$ alkotmánybírósági funkciót is betöltő észt legfelsőbb bíróság gyakorlatában csak elvétve jelennek meg a különleges jogrenddel kapcsolatos kérdések, ami nem meglepő, tekintettel arra, hogy bevezetésére eddig még sosem került sor. A bíróság a fegyveres erôk katasztrófahelyzetben történő alkalmazása kapcsán kimondta, hogy arra csak különleges jogrend esetén kerülhet sor. ${ }^{125}$ Komoly vitákhoz vezetett az a 2019-ben elfogadott törvényjavaslat, amely lehetôvé tette volna a Védelmi Erốk számára, hogy különleges jogrend, illetve veszélyhelyzet esetén hozzáférhessenek természetes és jogi személyek adataihoz, illetve egyéneket megfigyelés alá vegyenek. A köztársasági elnök megtagadta a törvény aláírását, és a legfelsőbb bíróságnak küldte meg azt, amely az elnök álláspontjával egyetértve alkotmányba ütközőnek találta a jogszabályt. ${ }^{126}$

A koronavírus-járvány idején bevezetett intézkedések kapcsán számos jogi eljárás indult. Például az Egészségügyi Minisztérium döntését a magánklinikák fogászati kezelésének ideiglenes beszüntetéséról bíróságon támadták meg, az Igazságügyi Minisztérium pedig megsemmisítette azt a helyi önkormányzati döntést, amely értelmében bizonyos közterületeket elzárnak a „kívülállóktól”, valamint bíróság vizsgálta felül szülők kezdeményezésére egy középiskola azon döntését, amely alapján a tavaszi szünetet eltörölték volna. ${ }^{127}$ Egy ügy a legfelsőbb bíróságig is eljutott, amely a Kulturális Minisztérium által a megszorult helyzetbe került kulturális intézményeknek juttatott rendkívüli támogatással volt kapcsolatos. A minisztérium ugyanis még a kapcsolódó kormányrendelet hatálybalépése előtti dátumot adott meg határidőként a támogatásért fordulók számára, így akadt olyan jelentkező, aki lecsúszott erről. Ezt a gyakorlatot a legfelsőbb bíróság az alkotmányba ütközőnek találta. ${ }^{128}$ Az észt igazságügyi biztos is fogalmazott meg kritikákat, így több panasz esetén is hangot adott annak a véleményének, hogy az önkormányzatok nem hozhatnak olyan rendeleteket, amelyek korlátozzák a lakosok alapjogait. ${ }^{129}$

124 Bővebben lásd: Parsovs, 2020.

125 Ügyszám: III-4/1-11/94, elérhető: www.riigiteataja.ee/kohtulahendid/detailid.html?id=206122715 (Letöltve: 2020. december 15.).

126 Ügyszám: 5-9-13, elérhető: https://freedomhouse.org/country/estonia/freedom-net/2020 (Letöltve: 2020 . december 15.).

127 Makarychev-Romashko, 2021.

128 Elérhető: https://news.err.ee/1216135/supreme-court-theater-missing-out-on-Covid-19-state-aid-unconstitutional (Letöltve: 2020 . december 15.).

129 Lásd például a 7-8/201491/2004979 ügyet és a 7-8/201491/2005008 ügyet. Elérhető: https://adr.rik.ee/okk/ dokument/7519681, valamint https://adr.rik.ee/okk/dokument/7525164 (Letöltve: 2020. december 15.). 


\section{5. Összegzés}

\begin{tabular}{|c|c|c|}
\hline & Szükségállapot & Hadiállapot \\
\hline $\begin{array}{l}\text { Szabályozás } \\
\text { szintje }\end{array}$ & \multicolumn{2}{|c|}{$\begin{array}{l}\text { Alkotmányos és törvényi } \\
\text { (Szükségállapoti tv., Honvédelmi tv.) }\end{array}$} \\
\hline $\begin{array}{l}\text { Elrendelési } \\
\text { okok }\end{array}$ & $\begin{array}{l}\text { - az alkotmányos rend megdöntésére } \\
\text { irányuló erőszakos kísérlet } \\
\text { — terrorista tevékenység } \\
\text { — erőszakos kollektív kényszerítés } \\
\text { — kiterjedt belső konfliktus különböző } \\
\text { csoportok között } \\
\text { - Észtország területe egy részének erő- } \\
\text { szakos elszigetelése } \\
\text { — tartós erőszakos belső konfliktus }\end{array}$ & $\begin{array}{l}\text { — külső fegyveres fenyegetés } \\
\text { — az országot külső agresszió éri }\end{array}$ \\
\hline Elrendelés & $\begin{array}{l}\text { A parlament rendeli el, a köztársasági } \\
\text { elnök, a kormány vagy a törvényhozás } \\
\text { képviselői többségének a javaslatára } \\
\text { az ország egész területén legfeljebb } \\
\text { három hónapos időtartamra. }\end{array}$ & $\begin{array}{l}\text { A parlament rendeli el a köztársasági } \\
\text { elnök javaslatára; } \\
\text { külső agresszió esetén a köztársasági } \\
\text { elnök maga dönthet. }\end{array}$ \\
\hline Felhatalmazott & $\begin{array}{l}\text { A rendkívüli helyzet kezeléséért felelős } \\
\text { vezető (miniszterelnök), kormány, belbiz- } \\
\text { tonságért felelős vezető (belügyminiszter) }\end{array}$ & $\begin{array}{l}\text { A védekezésért felelős vezető } \\
\text { (miniszterelnök), kormány, belügy- } \\
\text { miniszter, az Észt Védelmi Erők } \\
\text { parancsnoka }\end{array}$ \\
\hline $\begin{array}{l}\text { Előkészítő } \\
\text { szervek }\end{array}$ & $\begin{array}{l}\text { A kormány Válságbizottsága, Honvé- } \\
\text { delmi Tanács, Belügyminisztérium }\end{array}$ & $\begin{array}{l}\text { A kormány Biztonsági Bizottsága, } \\
\text { Honvédelmi Tanács, kancellária }\end{array}$ \\
\hline $\begin{array}{l}\text { Gyakorlati } \\
\text { esetek }\end{array}$ & \multicolumn{2}{|c|}{ Nincs } \\
\hline $\begin{array}{l}\text { Különleges } \\
\text { jogrendnek nem } \\
\text { minősülő rend- } \\
\text { kívüli helyzet }\end{array}$ & $\begin{array}{c}\text { Válsághelyzet, } \\
\text { veszélyhelyzet } \\
\text { (fokozatosság elve a veszélyhelyzetről } \\
\text { szóló törvény alapján) }\end{array}$ & Fokozott védelmi készültség \\
\hline
\end{tabular}

7. táblázat

Észtország különleges jogrendi szabályainak összegzése

Forrás: a szerző saját szerkesztése

Az észt különleges jogrenddel kapcsolatos alapvető szabályozás az alkotmányban található meg, amely a szükségállapotot és a hadiállapotot nevesíti. A két jogintézménnyel kapcsolatos szabályok többségét külön törvény tartalmazza: előbbi esetén a Szükségállapoti tv., utóbbinál a Honvédelmi tv. A szükségállapotot az Észtország alkotmányos rendjét, te- 
rületi egységét érő belső fenyegetések esetén lehet elrendelni. A hadiállapot esetén kizárólag az Észtországot érő külső agresszió kerül külön nevesítésre, ám ez csak a könnyebb bevezetést lehetôvé tevő rendelkezésnél, így feltehető, hogy alkalmazására más külső fegyveres fenyegetés esetén is van lehetőség.

A két különleges jogrendi esetkörhöz kapcsolódnak bizonyos rendkívüli helyzetek, amelyek megelőzik a különleges jogrend bevezetését. Ezek a szükségállapot esetén a Veszélyhelyzeti tv.-ben található válsághelyzet és veszélyhelyzet, míg hadiállapot esetén a fokozott védelmi készültség. A válsághelyzet az egyszerủ krízishelyzetnél súlyosabb esemény vagy alapvető szolgáltatást érintő leállás, amely hosszabb időtartamú, súlyosabb következményekkel jár, kezeléséhez a szokásosnál több erőforrás szükséges, ideértve adott esetben a külföldi országok és a nemzetközi szervezetek erőforrásait is, illetve együttmúködést igényel. A veszélyhelyzet még súlyosabb, itt ugyanis természeti katasztrófa, emberi tevékenység okozta katasztrófa, illetve fertőző betegség okozta vészhelyzet kezelésére vezetik be. Ennek bevezetéséről a kormány dönthet, a parlament bevonása nélkül. A fokozott védelmi készültség bevezetése szintén a kormány hatásköre, ám itt már szükséges a törvényhozás jóváhagyása is. Bevezetésére az Észtország biztonságát érintő nemzetközi fenyegetettség miatt vagy nemzetközi katonai műveletben való részvétel céljából kerülhet sor.

Észtország átfogó honvédelmi és nemzetbiztonsági politikával rendelkezik, vagyis a társadalom egésze bevonásra kerül a különleges jogrendi helyzetek kezelésébe. Ennek megfelelően az egyes esetkörök között fokozatosság áll fenn, és az egyes szintek a korábbi szinteknél meghatározott intézkedésekre épülnek. A veszélyhelyzet közben bevezethetô a szükségállapot is, ekkor a veszélyhelyzet kezelésével megbízott miniszter a miniszterelnök alárendeltje lesz. A veszélyhelyzet különlegesnek mondható, ugyanis a Veszélyhelyzeti tv. rendelkezéseit szükségállapot és hadiállapot idején is alkalmazni lehet. Ezzel szemben, ha bevezetésre kerül a hadiállapot, a szükségállapot azonnal megszúnik, és így a szükségállapoti törvény rendelkezéseit sem kell tovább alkalmazni.

Mindkét különleges jogrendi esetkörnél a parlament dönt annak elrendeléséről. Szükségállapot esetén erre javaslatot a kormány és a köztársasági elnök, illetve a törvényhozás képviselőinek többsége tehet. Hadiállapot esetén a köztársasági elnök jogosult javaslatot tenni. Az egyetlen kivétel az Észtországot ért külső agresszió, ebben az esetben a köztársasági elnök maga dönthet a hadiállapot bevezetéséről. A védekezésért felelős vezető mindkét esetben a miniszterelnök, aki így az egyik legfontosabb szereplőnek tekinthető a különleges jogrend idején. Mindkét esetkörben jelentős szerep jut a kormánynak, főleg a kapcsolódó rendkívüli jogszabályalkotásban. Szükségállapot idején a belső védelem vezetője, a belügyminiszter is igen fontos gyakorlati jogosítványokkal bír. Hadiállapot esetén is kap felhatalmazást a belügyminiszter, de ez jóval szúkebb körú, illetve az Észt Védelmi Erők parancsnoka is, aki akár utasításokat is figyelmen kívül hagyhat az eredményes védekezés érdekében.

A különleges jogrend bevezetésére való felkészülésben egy sor szerv játszik fontos szerepet. A veszélyhelyzet és a szükségállapot kapcsán ki kell emelni a kormány Válságbizott- 
ságát, míg a hadiállapot kapcsán a kormány Biztonsági Bizottságát. A köztársasági elnök mellett tanácsadó szervként múködő Honvédelmi Tanács mind a két különleges jogrendi esetkör bevezetése kapcsán fontos szereppel bír. Ezen stratégiai szervek mellett fontos szakpolitikai szervként jelenik meg a nemzetbiztonsági kérdésekben a Belügyminisztérium, míg a honvédelmi kérdésekben a kancellária.

Az alapjogok korlátozása terén kiemelendő, hogy az észt alkotmány az egyes alapjogoknál tesz említést azok korlátozhatóságáról, illetve a honvédelemről szóló fejezetben általánosságban kimondja, hogy az alkotmányban és a törvényekben foglalt alapjogok korlátozhatók különleges jogrend idején. Ugyanezen passzus meghatározza a korlátozhatatlan alapjogok listáját is. A Szükségállapoti és Honvédelmi tv. részletesen tartalmaz rendelkezéseket az alapjogok korlátozásával kapcsolatban. A válsághelyzet során történő alapjogkorlátozás ugyanakkor aggályokat vet fel, hiszen ez az esetkör nem tekinthető különleges jogrendnek, nem kerül nevesítésre az alkotmányban sem, és annak bevezetése nem igényel parlamenti hozzájárulást sem.

A magyar különleges jogrendi rezsimmel összehasonlítva elmondhatjuk, hogy a jelenlegi magyar szabályozásnál jóval átgondoltabb koncepciót valósít meg, amelynél nemcsak az esetkörök száma jóval kisebb (kettő az észt, míg hat a magyar jogrendszerben). A két észt esetkör közül a hadiállapot a súlyosabb, annak érvényesülése esetén a szükségállapot megszûnik. Ezekhez a fokozatosság elve alapján enyhébb, rendkívüli felhatalmazással járó jogintézmények is kapcsolódnak, amelyek közül kettő a magyar jogban különleges jogrendnek minősül: a veszélyhelyzet, illetve az észt fokozott katonai készültséggel párhuzamba állítható megelőző védelmi helyzet. Az észt fokozatos rendszer lehetôvé teszi a fenyegetések differenciált leküzdését, és utolsó eszközzé teszi a különleges jogrendet, annak eredeti rendeltetésének megfelelôen. Ugyanakkor ebből bizonyos alkotmányos problémák is keletkeznek, különösen a veszélyhelyzet terén, ahol nem szükséges a parlament jóváhagyása még utólagos formában sem, mint a magyar jogrendszerben.

Az Alaptörvény 9. módosításával jelentősen hasonlóbb lesz az észt és a magyar különleges jogrendi rendszer. Megjelenik idehaza is a hadiállapot kifejezés, mellette megmarad a szükségállapot és a veszélyhelyzet. A fó különbség így már inkább csak az észt fokozatossági rendszerben lesz, a jogintézmény eltérő szintjében a veszélyhelyzet és a fokozott védelmi készültség vonatkozásában. Különbségként állapítható még meg, hogy az észt szükségállapot egyértelmúen tartalmazza a terrorcselekményeket - ez idehaza az új szövegben sehol sem került nevesítésre -, valamint az ország egy részének erővel történő elszakítását is. Ez utóbbi bizonyosan az orosz ajkú lakosság miatt került a törvénybe, ami geopolitikai sajátosság Ukrajna elszakított területeinek példája alapján. Kiemelhető még az eltérő szabályozási megoldás is: míg az észt alkotmány csak minimumszabályokat tartalmaz, és részletes törvény foglalkozik a különleges jogrendi esetkörökkel, addig az Alaptörvénybe azok részletes szabályozását foglalták. 
Különbség mutatkozik az elrendelésben is: míg az észteknél a parlament rendeli el őket, addig idehaza, bár a legtöbb esetben az Országgyúlés jogosult erre, két esetkörben a Kormány rendelkezik erről. Az új Alaptörvény-módosítás alapján ez a szabályozás is jóval hasonlóbbá válik: a hadiállapot és a szükségállapot bevezetéséról az Országgyuulés, a veszélyhelyzet bevezetéséről a Kormány dönt. A veszélyhelyzet kapcsán különbségként állapítható meg azonban, hogy idehaza csak korlátozott időre hozható és csak az Országgyưlés döntése alapján hosszabbítható meg, míg Észtországban a parlamentnek semmilyen módon nem kell hozzájárulnia ahhoz, az teljesen a kormány hatáskörébe tartozik.

A felhatalmazás jelenlegi szabályai kapcsán elmondható, hogy az észt rendszerben nagy szerep jut a miniszterelnöknek, aki a különleges jogrend kezeléséért felelős vezetőként számos jogosultsággal bír, mellette a kormány a legfontosabb szerv, míg a tényleges operatív feladatokat a belügyminiszter, illetve hadiállapot esetén a védelmi erők parancsnoka látja el. Ezzel szemben idehaza elmondható, hogy a miniszterelnök nem kerül külön kiemelésre jogszabályi szinten és pluszjogosítványai sincsenek, a Kormány vezető szerepe pedig nem minden esetben egyértelmú: rendkívüli állapot esetén feladatait a Honvédelmi Tanács veszi át, míg szükségállapot idején nagyobb szerep jut a köztársasági elnöknek. Az új szabályozásban ez is megváltozik, a Kormány egyértelmú primátusra tesz szert a különleges jogrend minden esetköre során.

Az alapjogok korlátozása kapcsán elmondható, hogy mind a két szabályozás hasonló megoldással, a korlátozhatatlan alapjogok listájának megadásával operál, ugyanakkor megjegyezhető, hogy az Alaptörvényben sokkal átláthatóbban jelennek meg az egyes alapjogok. Észt sajátosságként meg kell azonban azt is jegyezni, hogy nem csak az alkotmány állapíthat meg alapjogokat.

A válságkezelés vonatkozásában szintén az észt jogrendszer megoldása tekinthető jobbnak: a válsághelyzetek külön törvényekben történő szabályozása helyett egy átfogó Veszélyhelyzeti tv. foglalkozik ezekkel, így jóval egységesebben valósulhat meg a válságkezelés, és átláthatóbb az ezzel kapcsolatos szabályozás. A válsághelyzet ráadásul egységes fogalmi keretek között kerül meghatározásra, amelynek átültetését a hazai jogalkotó számára is érdemes lenne megfontolni. Itt is jut ugyanakkor szerep az ágazati sajátosságoknak, például a fertőző betegségek kapcsán külön törvénybe foglalt intézkedések hozhatók, ugyanakkor ezek nem tekintendők jogi értelemben válsághelyzetnek. 


\section{Irodalomjegyzék}

Dubrovnik, T. (2009) 'The Position, Election and Powers of the President of the Republic of Estonia', Lex localis - Journal of Local Self-Government, 7(1), 19-32. o.

Gross, O. (2004) 'Providing for the Unexpected: Constitutional Emergency Provisions' in Dinstein, Y., Domb, F. (szerk.) Israel Yearbook of Human Rights. 1. kiadás. Tel Aviv: Faculty of Law of Tel Aviv University

KENKMANN, P. (2018) '„Universal Means of Governance”: the State of National Emergency in the Republic of Estonia in 1938-1940', TUNA, 21(1), 20-38. o.

Lane, T., Pabriks, A., Purs, A., Smith, D. J. (2013) The Baltic States: Estonia, Latvia and Lithuania. 1. kiadás. London-New York: Routledge

Loeber, D. A. (1998) 'Regaining Independence - Constitutional Aspects: Estonia, Latvia, Lithuania', Review of Central and East European Law, 24(1), 1-7. o.

Makarychev, A., Romashro, T. (2021) 'Precarious Sovereignty in a Post-liberal Europe: The COVID-19 Emergency in Estonia and Finland', Chinese Political Science Review, 6(1), 63-85. o.

Maruste, R. (2020) State of Emergency in Estonia [Online]. Elérhető: https://verfassungsblog. de/state-of-emergency-in-estonia/ (Letöltve: 2020. december 3.)

Osula, A. (2015) National Cyber Security Organistation: Estonia [Online]. Elérhető: https:// ccdcoe.org/uploads/2018/10/CS_organisation_ESTONIA_032015_1-1.pdf (Letöltve: 2020. december 3.)

PARsovs, A. (2020) 'Solving the Estonian ID Card Crisis: the Legal Issues' in Hughes, A. L., McNeill, F., Zobel, C. (szerk.) Proceedings of the 17th ISCRAM Conference - Blacksburg, VA, USA May 2020. 1. kiadás. CoRe Paper - Ethical, Legal, and Social Issues

SMITH, D. (2001) Estonia: Independence and European Integration. 1. kiadás. London: Routledge

VALGE, J. (2012) 'Foreign Involvement and Loss of Democracy, Estonia 1934', Journal of Contemporary History, 46(4), 788-808. o.

Veebel, V. (2017) Planning and Developing the Estonian Military Forces: Progress, Challenges and Dilemmas. 1. kiadás. Tallinn: Estonian Foreign Policy Institute

Veebel, V., Ploom, I. (2019) 'Estonia's Comprehensive Approach to National Defence: Origins and Dilemmas', Journal on Baltic Security, 4(2), 10-22. o.

Venice Commission (2020) Interim Report on the Measures Taken in the EU Member States as a Result of the Covid-19 Crisis and Their Impact on Democracy, the Rule of Law and Fundamental Rights (Opinion No. 995/2020) [Online]. Elérhető: www.venice.coe.int/webforms/documents/ default.aspx?pdffile=CDL-AD(2020)018-e (Letöltve: 2020 . december 15.) 